\title{
PREDICTION MODEL OF INFLUENCE OF FORCE ON LAND AND PERFORMANCE IN FIN SWIMMING, A PILOT STUDY
}

\author{
Georgia Rozi, Vassilios Thanopoulos \\ National and Kapodistrian University of Athens, Faculty of Physical Education and Sports, \\ Department of Aquatic Sports, Athens, Greece
}

\begin{abstract}
The purpose of this research is the determination of a prediction model that could predict $50 \mathrm{~m}$ and $100 \mathrm{~m}$ fin swimming results on surface. The sample of this research consisted of 9 fin swimmers of competitive level. All participants swam 50 and 100 meters on the water surface with monofin and a snorkel with maximum intensity. In two next sessions, force of the leg extensors and ankle extensors were measured in the workout gym with a dynamometer. The results of this study concluded in a potential statistical significance of regression analysis for $50 \mathrm{~m}$ fin swimming with snorkel on the surface of the water. Relative force values of ankle and leg extensors are better predictors of $50 \mathrm{~m}$ fin swimming. No similar results were found for $100 \mathrm{~m}$ fin swimming. These findings probably suggest that in shorter distance of $50 \mathrm{~m}$ fin swimming, force variables of extensor muscles play a greater role in comparison to longer distance of $100 \mathrm{~m}$ fin swimming. The measurement of force of legs in fin swimming is of particular interest because legs are mostly responsible for the propulsion in fin swimming and should further be studied with other force protocols, different exercises and larger sample.
\end{abstract}

Keywords: MESURAMENT IN SWIMMING / DYNAMOMETRY / MONOFIN / PREDICTION MODEL

\section{INTRODUCTION}

Monofin swimming is a movement of the swimmer's body through water, in a wavy line, in which the movement of legs is maximal, while the movement of the upper body is minimal. To achieve this, the body must be aligned with the arms stretched above his head while hands crosslinked (the inner part of the hands facing the bottom of the pool). Respiration is done by ventilation (snorkel) through the mouth which is fixed to the head. Fin swimming is a sport of speed, and it takes place on the water surface and underwater. In fin swimming speeds of $3,89 \mathrm{~m} / \mathrm{s}$ are achieved (Vogel, 1994). The movement of the swimmer resembles the movement of dolphins and the propulsion needs a movement of the entire body (Videler, 1981). The arms and hands are not used for the propulsion of the body (Gautier et al., 2004).
Different distances and different types of fins and equipment are used in competition. Clearly, improved materials of fins and equipment are generally responsible for the improved performance, despite the fact that the design of monofin is still empirical (Bideau et al., 2002).

The most significant contribution to the development of high speed is derived from the construction of the monofin which was adjusted to competition and training program (Zamparo, Prendergast, Termin \& Minetti, 2002).

Researches on fin swimming were intensified after the invention of the monofin and the new method of propulsion in water (Pendergast, Tedesco, Nawrocki \& Fisher, 1996). The movement with monofin as a new way to swim forced the researchers to turn their interest in fin swimming as a particular sport.

Scientific studies on the preparation of fin swimming athletes appeared in the decade of 1980 (Popov, 1982; Zammartini, 1986). Few studies exist on the effects of training in the art of swimming. 
Apart from the necessary qualitative execution of technical elements of swimming (Dopsaj, et al 2000b), characteristics of force provide important information and play a decisive role in the competition of 50 and 100 meters fin swimming. Propulsion bears on the vertical displacement of the whole body. The use of the upper body is forbidden for propulsion purposes. The vertical displacement of the body during the stroke cycle has been described as wave-like (Ungerechts, 1982). Since such motion could be characterized by specific amplitudes of oscillations. Such oscillations were also specified by a particular frequency and phase relationship (Sanders et al., 1995).

Another study revealed the effect of the monofin shape on the propulsive forces by analyzing the change in the swimmer's velocity over one cycle of the monofin's motion (Tamura et al., 2002).

Measurement of muscle force is performed using a dynamometer, and in the attempt to obtain the most accurate data, precision electronic devices are applied. In the measurement of force of various muscle groups using a dynamometer, there is a different development trend. The difference of athlete's strength is changing through the years.

Monofin swimming is very interesting concerning the force application. The swimmer and monofin share a mechanical interaction, that is, the swimmer can transmit the force to the monofin to drive it, and the monofin returns the reaction to the swimmer. This interactive relationship determines the total swimming performance (Nakashima, Suzuki \& Nakajima, 2010). The present research is an attempt to measure the force out of the water, of muscle groups that play an important role in fin swimming.

The purpose of this research was the determination of force parameters of selected muscle group that, should predict of performance of $50 \mathrm{~m}$ and $100 \mathrm{~m}$ fin swimming

\section{METHOD}

\section{Sample}

The sample consisted of 9 athletes of fin swimming and competitive level, age: $17.0 \pm 0$ years, height: $176 \pm 5 \mathrm{~cm}$ and weight: $72 \pm 5 \mathrm{~kg}$. Their training age was 5 years. The study was approved by the Ethical Committee of Athens University.

\section{Procedures}

The measurements were performed in an outdoor swimming pool 50m length and $3 \mathrm{~m}$ depth (Olympic size). The water temperature was $26^{\circ}$. The measurements took place at midday between 12:00 to $14: 00$, because this was the time of their training session.

All measurements were made 15 days before the main competition of the summer cycle, in random order. Body height $(\mathrm{cm})$ and weight $(\mathrm{kg})$ were measured with minimum athletic attire (swimsuits) in the gym of the swimming pool.

The athletes were informed about the purpose of the investigation, the potential risks and procedures of measurements, and they gave their written consent with their parents. All swimmers involved in daily training lasting two hours and at least five days per week.

In the first session swimmers made the same warm up of $1000 \mathrm{~m}$ under the guidance of their coach. Ten to fifteen minutes after, they swam with maximum intensity the distance of 50 meters on the surface of the water with a ventilator (snorkel) and the monofin adjusted to their feet. In the next session on a different day, they swam the distance of 100 meters with the same conditions. Before each test, heart rate was measured to reassure that participants have a heart rate of low and equal level.

Both measurements started from the starting block. Immediately after the efforts, heart rate and performance time were recorded with a stopwatch (Seiko Water Resistant 10bar S140).

In the last session, on different day in two subsequent measurements, the force of the ankle extensor (Image 1) and the leg extensors (Image 2) were recorded with a dynamometer (IMADA) in the gym where the dry land workout takes place.

For the measurement of isometric force of ankle extensors, the swimmers were sitting on a chair and were asked to lift their ankles against a thick wooden platform that was fixed on their legs and connected to the dynamometer. The angle of both knees was same for all participants, 90 degrees. 
For the second measurement of isometric force of leg extensors, swimmers were standing with their knees slightly bend and with their hands straight next to their hips holding a handle connected to the dynamometer and were asked to straighten their knees.

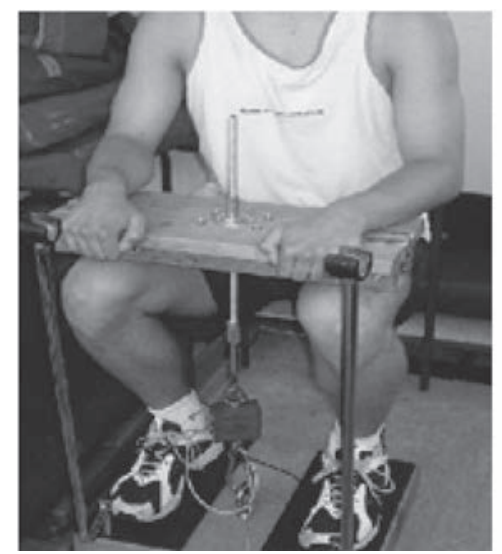

Fig. 1. Ankle extensors measurement with dynamometer.

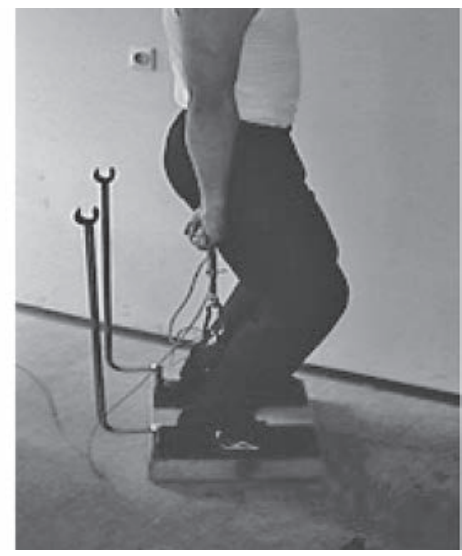

Fig.2. Leg extensors measurement with dynamometer.

All of the data were automatically stored in the computer memory using the appropriate «Imada software», connected with the dynamometer (Pro-Ing system, Serbia). For the analysis of the results, maximum force of each measurement was used. Furthermore, relative value of isometric force was calculated and used in the prediction model of $50 \mathrm{~m}$ and $100 \mathrm{~m}$ fin swimming. Relative force values (Frel ) were calculated according to the maximum values obtained in previous Fmax values divided by body weight.

\section{Variables}

Variables that accrued of the measurements and calculation were:
- Fmax of leg extensors- average of maximum muscle pulling force (peaks) for leg extensors, given in $\mathrm{N}$.

- Fmax of ankle extensors- average of maximum muscle pulling force (peaks) for ankle extensors, given in $\mathrm{N}$.

- Frel of leg extensors- relative force for ankle extensors.

- Frel of ankle extensors--relative force for ankle extensors.

\section{Statistical analysis}

All data went through a descriptive statistical analysis. For the analysis of force and swimming performance multiple regression analysis was applied in order to determine the variables that best describe $50 \mathrm{~m}$ and $100 \mathrm{~m}$ fin swimming. Values are expressed in mean values and standard deviations. The significance level for all parameters was set at $\mathrm{p}<0.05$. Data analysis was done with the statistical program SPSS 22.

\section{RESULTS}

Descriptive statistics of the variables are shown in Table 1.

Table 1. Means and standard deviation of measured variables.

\begin{tabular}{|c|c|}
\hline $\begin{array}{c}\text { Time 50m fin swimming } \\
\text { (secs) }\end{array}$ & Mean \pm SD \\
\hline $\begin{array}{c}\text { Time 100m fin swimming } \\
\text { (secs) }\end{array}$ & $45.7956 \pm 2.56$ \\
\hline Fmax Leg Ext (N) & $948.0 \pm 159.17$ \\
\hline Fmax Ankle Ext (N) & $2872.87 \pm 577.35$ \\
\hline Frel Leg Ext (N) & $13.31 \pm 2.52$ \\
\hline Frel Ankle Ext (N) & $40.15 \pm 7.58$ \\
\hline
\end{tabular}

Multiple regression model explained $64.1 \%$ of dependent variable (Adj. $\mathrm{R}^{2}=0.641$ ) 'fin swimming time at $50 \mathrm{~m}$, $(50 \mathrm{~m}$ fin swimming average results = $19.8878 \pm 0.9231 \mathrm{secs}$ ). Regression model for $50 \mathrm{~m}$ was not generally statistically significant (Sig. .085). We could say that these results are potentially statistically significant because $\mathrm{p}$ is less than 0.100 , which means statistical probability is $91.5 \%$. The results of the multiple regression analysis concerning $50 \mathrm{~m}$ fin swimming on surface are shown in Table 2. 
Table 2. Regression analysis for $50 \mathrm{~m}$ fin swimming results.

\begin{tabular}{|c|c|c|c|c|c|c|}
\hline \multicolumn{2}{|c|}{ Model } & $\begin{array}{c}\text { Sum of } \\
\text { Squares }\end{array}$ & df & $\begin{array}{c}\text { Mean } \\
\text { Square }\end{array}$ & F & Sig. \\
\hline \multirow{2}{*}{1} & Regression & 5.593 & 4 & 1.398 & 4.571 & $.085^{\mathrm{a}}$ \\
\cline { 2 - 7 } & Residual & 1.224 & 4 & .306 & & \\
\cline { 2 - 7 } & Total & 6.817 & 8 & & & \\
\hline
\end{tabular}

Furthermore, at partial level all single variables explain statistically significantly $50 \mathrm{~m}$ fin swimming results at $0.015,0.019,0.016$ and $0.020 \mathrm{p}$ level, respectively, but as a group of variables no general significant explanation can occur.

The Prediction Model Equation for 50m Fin swimming time is:

50m Fin Swim Time $=25.1023-($ Legs_Ext_Fmax

-0.1130 $)+($ Ancle_Ext_Fmax • 0.0346 $)+($ Legs_

Ext_Frel • 7.7764) - (Ancle_Ext_Frel • 2.5149)

As shown by the analysis of the results, relative results (Frel) have greater influence at $50 \mathrm{~m}$ results than absolute results (Fmax).

Concerning the results of $100 \mathrm{~m}$ fin swimming with snorkel, no statistical significance occurred. None of the force variables describe sufficiently the dependent variable ' $100 \mathrm{~m}$ time in fin swimming', all four variables were removed with $\mathrm{p}$ values $.981, .929$, $.809, .537$, respectively for each model. Furthermore, no significant results were presented in partial level.

\section{DISCUSSION}

The results of this study concluded in a potential statistical significance of regression analysis for $50 \mathrm{~m}$ fin swimming with snorkel on the surface of the water. Relative force values of ankle and leg extensors are possible predictors of $50 \mathrm{~m}$ fin swimming. The prediction model that occurred is:

50m Fin Swim Time $=25.1023-$ (Legs_Ext_Fmax -0.1130 $)+($ Ancle_Ext_Fmax • 0.0346) $+($ Legs_Ext_ Frel • 7.7764) - (Ancle_Ext_Frel • 2.5149)
No similar results were found for $100 \mathrm{~m}$ fin swimming. These findings probably suggest that in shorter distance of 50m fin swimming, force variables of extensor muscles play a greater role in comparison to longer distance of $100 \mathrm{~m}$ fin swimming.

Previous study concerning classical swimming (Dopsaj et al., 2004) found that explosiveness of back, feet and ankle extensors can be significant predictors of performance of 50 and $100 \mathrm{~m}$ swimming.

In the field of monofin swimming, there is not enough bibliography that has to do with dry land measurements of force. Most of the research concerning monofin swimming has to do with kinematic analysis of the movement of the fin and the swimmer (Rejman, 2013; Rejman, Klarowicz \& Zaton, 2012).

Further research is needed in order to determine a procedure that will control swimmer's fitness levels on land not only to enable more accurate management of the training process either in water or on land, but also to enhance the effectiveness of training and raise the competitive fitness levels in sprint monofin swimmers.

\section{CONCLUSION}

Limitations of this research (sample size) could not permit statistical significance of the regression model for $50 \mathrm{~m}$ fin swimming, whereas all force parameters resulted in significant predictors in partial level.

Lack of significant results in $100 \mathrm{~m}$ fin swimming in this study emphasize the need of further research in dry land measurements connected to monofin swimming.

Such a measurement, which can yield high quality information on an athlete's actual level of competitive fitness, is very important both to the trainer and the athlete, as to the control of the effects of the training methods employed in the preparation period, and to the fitness status on land with respect to explosiveness, which is an essential part of training technology. 


\section{REFERENCE}

1. Bideau, B., Colobert, B., Fusco, N., Cretual, A., Multon, F., \& Delamarche, P. (2002). How to Compute the Mechanical Parameters of Monofins. Proceedings of Biomechanics and Medicine in Swimming IX. (pp. 505-510). Saint-Etienne, France.

2. Dopsaj, M., Matković, I., \& Zdravković, I. (2000b). The relationship between 50m - freestyle results and characteristics of tethered forces in male sprint swimmers: A new approach to tethered swimming test. Facta Universitatis Series: Physical Education and Sport, 1(7), 15-22.

3. Dopsaj, M., Thanopoulos, V., Vojko, R., \& Tomislav, O. (2004). The relationship between between competitive fitness levels in top sprinters swimmers at 50 and $100 \mathrm{~m}$. freestyle and indicators of explosiveness of different muscle groups: A result prediction model. $4^{\text {th }}$ International Conference on Strength Training. Book of Abstracts (pp 153-154). Serres, Greece.

4. Gautier, J., Baly, L., Zanone,P. G., \&Watier, B. (2004). Effect of practice level and race distance on Kinematics parameters in fin swimming. Sciene \& Sports, 3, 91-95.

5. Nakashima, M., Suzuki, S., \& Nakajima, K. (2010). Development of a simulation model for monofin swimming. Journal of Biomechanical Science and Engineering, 5(4), 408-420.

6. Pendergast, D. R., Tedesco, M., Nawrocki, D. M., \& Fisher, N. M. (1996). Energetics of underwater swimming with SCUBA. Medicine and Science in Sports and Exercise, 28, 573-580.

7. Popov, F.P. (1982). Preparation of high class sailors (Translation Vourna A.) Athens: EOUDA.
8. Rejman, M. (2013). Analysis of relationships between the level of errors in leg and monofin movement and stroke parameters in monofin swimming. Journal of sports science and medicine, 12, 171-181.

9. Rejman, M., Klarowicz, A., \& Zaton, K. (2012). An evaluation of kinesthetic differentiation ability in monofin swimmers. Human movement, 13(1), 8-15.

10. Sanders R. H., Cappaert J. M., Devlin R. K. (1995) Wave characteristics of butterfly swimming. Journal of Biomechanics 28, 9-16.

11. Tamura H., Nakazawa Y., Sugiyama Y., Nomura T., Torii N. (2002) Motion analysis and shape evaluation swimming monofin. : The Engineering of Sport. Ujihashi S., Haake S.J., editors. Blackwell Science, Vol. 4, 716-724

12. Ungerechts B. E. (1982) A comparison of the movements of the rear parts of dolphins and butterfly swimmers (215-221). Biomechanics and Medicine in Swimming. Hollander A. P., Champaign, Human Kinetics,

13. Videler, J. (1981). Swimming movement, body structure and propulsion. Cod Gadusmorhua, Symposia of the Zoological Society of the London, 48, 1-27.Zammartini, S. (1986). Swimming Training Technique (Translation by Liulias A.) Athens: EOUDA.

14. Zamparo, P., Prendergast, D. R., Termin, B. \& Minetti, A. E. (2002). How fins affect the economy and efficiency of human swimming. Journal of Experimental Biology, 205, 2665-2676. 


\title{
MODELO DE PREDICCIÓN DE LA INFLUENCIA DE FUERZA EN LO SECO Y EL RENDIMIENTO EN LA NATACIÓN CON ALETAS - ESTUDIO PILOTO
}

\begin{abstract}
Resumen
El objetivo de la presente investigación es determinar el modelo de predicción que podría prever los resultados de natación con aletas a $50 \mathrm{~m}$ y a $100 \mathrm{~m}$. La muestra de esta investigación han sido los 9 nadadores con aletas a nivel de competencia. Todos los participantes nadaron con la intensidad máxima con aletas monofin con tubo respetador a 50 y a 100 metros en la superficie del agua. En dos siguientes fases la fuerza de los músculos extensores de piernas y de los musculáis extensores de pierna inferior se ha medido en el gimnasio por dinamómetro. Los resultados de esta investigación han llevado hasta la conclusión sobre la posible importancia estadística del análisis de regresión de la natación con aletas a $50 \mathrm{~m}$ con tubo respirador en la superficie del agua. Los valores de la fuerza relativa de los músculos extensores de la pierna inferior y de la pierna son mejores predictores para la natación a $50 \mathrm{~m}$ con aletas. Los resultados parecidos no se han obtenido en la natación con aletas a $100 \mathrm{~m}$. Estos descubrimientos probablemente sugieren que a distancias más cortas en la natación con aletas a $50 \mathrm{~m}$ las variables de fuerza de los músculos extensores juegan un mayor papel en comparación con la natación a una mayor distancia, natación con aletas a $100 \mathrm{~m}$. La medición de la fuerza de las piernas en la natación con aletas tiene una importancia especial teniendo en cuenta que las piernas en general son responsables para la propulsión en la natación con aletas y hace falta seguir investigando con otros protocolos de fuerza, distintos ejercicios y en una muestra mayor.
\end{abstract}

Palabras claves: MEDICIÓN EN LA NATACIÓN/ DINAMOMETRÍA / ALETAS MONOFIN / MODELO DE LA PREDICCIÓN

Reacived: 11.06. 2017

Accepted: 04.12. 2017. 


\title{
МОДЕЛ ПРЕДИКЦИЈЕ УТИЦАЈА СИЛЕ НА СУВОМ И ПЕРФОРМАНСЕ У ПЛИВАЊУ СА ПЕРАЈАМА, ПИЛОТ СТУДИЈА
}

\author{
Георгиа Рози, Василиос Танопулос \\ Национални и Каподистријасов универзитет у Атини, Факултет физичког васпитања и спорта, \\ Одсек за спортове на води, Грчка
}

\begin{abstract}
Сажетак
Циљ овог истраживања је одређивање модела предикције који би могао да предвиди резултате пливања са перајама на 50м и 100м. Узорак овог истраживања чинило је 9 пливача са перајама на такмичарском нивоу. Сви учесници су пливали максималним интензитетом са монофин перајама са дисаљком на 50 и 100 метара на површини воде. У следеће две фазе, снага мишића опружача ногу и мишића опружача потколенице, мерена је у теретани динамометром. Резултати овог истраживања су довели до закључка о могућем статистичком значају регресионе анализе пливања са перајама на 50м са дисаљком на површини воде. Вредности релативне силе мишића опружача потколенице и ноге су бољи предиктори за пливање са перајама на 50м. Слични резултати нису добијени код пливања са перајама на 100м. Ова открића вероватно сугеришу да су на краћим раздаљинама код пливања са перајама на 50м, варијабле силе мишића опружача играју већу улогу у поређењу са већом раздаљином у пливању са перајама на 100м. Мерење силе ногу у пливању са перајама је од посебног значаја, пошто су ноге углавном одговорне за пропулзију код пливања са перајама и треба их даље истраживати другим протоколима силе, различитим вежбањима и на већем узорку.
\end{abstract}

КљУчНе речИ: МЕРЕЊЕ У ПЛИВАЬУ / ДИНАМОМЕТРИЈА / МОНОФИН ПЕРАЈА / МОДЕЛ ПРЕДИКЦИЈЕ

\section{УВОД}

Пливање са монофин перајама је кретање тела пливача кроз воду, током кога се региструју оптимални покрети у зглобовима ногу, док је покретање горњег дела тела минимално. Да би се то постигло, тело мора бити у идеално глисирајућој позицији, са рукама испруженим изнад - испред главе, док су шаке унакрсно спојене (палмарни део шака окренут ка дну базена). Дисање се врши кроз дисаљку која је причвршћена за главу.

Пливање са перајама је брза спортска дисциплина и дешава се на површини и испод површине воде. Код пливања са перајама постиже се брзина од 3,89м/c (Vogel, 1994). Покрети пливача подсећају на покрете делфина, а за пропулзију према напред је потребна кретња читавог тела (Videler, 1981). Руке и шаке се не користе за веслање и померање тела (Gautier et al., 2004).
На такмичењима спортисти пливају различите такмичарске дужине и са различитом врстом пераја и опреме. Јасно је да је унапређење материјала од којих су сачињена пераја и опрема углавном „одговорне“ за побољшање такмичарских резултата, и упркос чињеници да је постојећи дизајн монофин пераја још увек емпиријски (Bideau et al., 2002). Најзначајнији допринос развоју велике брзине је настао захваљујући конструкцији монофин пераја која су прилагођена за такмичења и тренажни програм (Zamparo, Prendergast, Termin \& Minetti, 2002).

Истраживања о пливању са перајама су учестала после проналаска монофин пераја као потенцијално новог пропулзивног погона у води (Pendergast, Tedesco, Nawrocki \& Fisher, 1996). Покрет монофин перајама, као нови начин пливања, натерао је истраживаче да своје интересовање окрену пливању са перајама као посебном спорту. 
Научна истраживања о припреми спортиста за пливање са перајама појавило се осамдесетих година прошлог века (Popov, 1982; Zammartini, 1986). Ипак, и данас је мало истраживања о ефектима транинга на вештину и ефикасност пливања.

Осим неопходног квалитетног извођења техничких елемената пливања (Dopsaj i sar. 2000б), особине мишићне силе пружају важне информације и играју одлучујућу улогу у припреми и самом такмичењу у пливању са перајама на 50 и 100 метара. Пропулзија се односи на померање читавог тела. За стварање пропулзије забрањено је коришћење горњег дела тела. Вертикално померање тела током циклуса удараца се описује као таласасто (Ungerechts, 1982). Покрети током овог пливања могу да се окарактеришу специфичним вертикалним амплитудама - осцилациje, које карактерише посебна фреквенција и фазни однос (Sanders et al 1995). Један број истраживања је пратио ефекте облика монофин пераја на силу пропулзије, док се један број бавио анализом промене у брзини пливања током једног циклуса покрета монофин пераја (Tamura et al, и сар., 2002). Мерење снаге мишића се врши динамометром. Са циљем да се измере тачни подаци, примењују се прецизни електронски уређаји. Могуће је утврдити различите правце током развоја метода за мерење снаге различитих мишићних група коришћењем динамометра. Оно што је важно истаћи је чињеница да се разлика у измереној сили код спортиста мења током тренажне године.

Пливање са монофин перајама је веома интересантно са позиције сазнања о утицају мишићне силе. Пливање са монофин перајама се одвија кроз механичку интеракцију пливача и водене средине, то јест, пливач преноси силу за кретање на монофин пераје, док само пераје узвраћа реакцијом на пливача и његово кретање пливањем. Овај интерактивни однос одређује укупну перформансу пливања (Nakashima, Suzuki \& Nakajima, 2010). Сходно наведеном, предмет ове пилот студије је мерење силе мишићних група које играју важну улогу код пливања перајама. Циљ студије је детерминисање параметара силе изабраних мишићних група на основу којих би се могли предвидети перформансе у пливању са перајама на 50 и 100м.

\section{МЕТОД}

\section{Узорак испитаника}

Узорак је бројао 9 спортиста који се баве пливањем са перајама на такмичарском нивоу, старости: 17,0 0 година, висине: $176 \pm 5$ цм и тежине: $72 \pm 5 \kappa г$. Дужина тренирања је била 5 година. Студију је одобрио Етички комитет Универзитета у Атини.

\section{Процедура мерења}

Мерења су вршена на отвореном базену, дужине 50м и дубине 3м (олимпијски базен за ОИ у Атини, 2004). Температура воде је била $26^{\circ} \mathrm{C}$. Мерења су вршена средином дана између 12:00 и 14:00 часова током редовних тренажних термина.

Сва мерења су вршена насумичним редоследом 15 дана пре главног такмичења у летњем циклусу. Телесна висина (цм) и тежина (кг) мерени су са минимумом спортске одеће (костим за пливање) у теретани која се налази непосредно уз базен.

Спортисти су информисани о сврси испитивања, могућим ризицима и процедурама мерења. Дали су писмену сагласност заједно са родитељима. Сви пливачи су били укључени у дневно тренирање које је трајало по два часа и одвијало се бар пет пута недељно.

У првој фази припреме за мерење, пливачи су се на исти начин загревали пливањем на 1000м под вођством свог тренера. Десет до петнаест минута после тога пливали су максималним интензитетом растојање од 50м на површини воде са дисаљком и подешеним монофин перајама. У следећој фази, наредних дана, препливали су раздаљину од 100м под истим условима. Пре сваког теста мерен је пулс (фреквенција срчаног рада) са циљем да би се осигурало да учесници имају оптимални и радни пулс на подједнаком нивоу.

Мерења су започињала скоком са стартног блока. Непосредно по завршетку пливања регистровани су време пливања и фреквенција срца (Seico Water Resistant 10bar S140). У последњој фази мерења, различитог дана, вршена су мерења мишићне силе динамометром (IMADA) мишића опружача потколенице (слика 1) и мишића опружача ногу (слика 2). За мерење изометријске силе мишића опружача потколенице, пливачи су седели на столици са чланцима уздигнутим дрвеном платформом. Угао у зглобовима колена је био 90 степени и био је исти за све учеснике. 
За мерење изометријске силе мишића опружача ноге, пливачи су стајали са коленима лако савијеним и рукама опруженим поред кукова држећи ручицу повезану са динамометром (Слика 2).

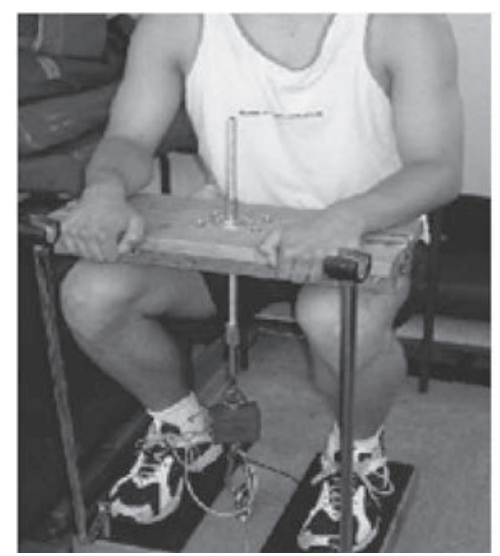

Слика 1. Мерење мишића опружача потколенице динамометром

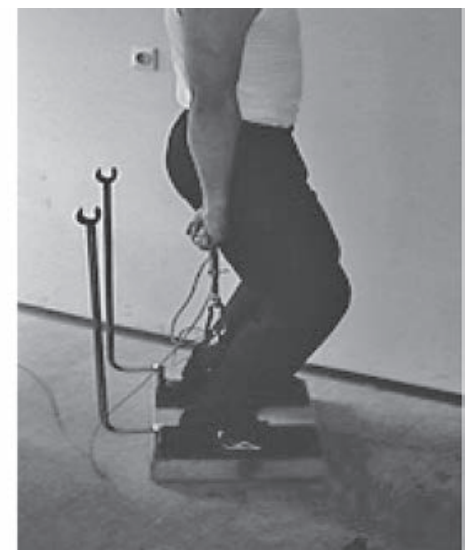

Слика 2. Мерење мишића опружача ногу динамометром

Сви подаци добијени пливачким и мерењима мишићне силе су аутоматски складиштени у меморију рачунара. Мерење мишићне силе је вршено путем динамометра Про-Инг систем, Србија. Подаци су обрађени кроз „Имада софтвер“. За анализу је коришћена максимална сила регистрована током сваког мерења. Даље су израчунаване релативне вредности изометријске силе које су коришћене у моделу предикције за пливање перајама на $50 \mathrm{~m}$ и $100 \mathrm{~m}$. Вредности релативне силе (F-rel.) су израчунаване према максималним вредностима добијеним у претходним Fmax.

\section{Варијабле мишићне силе}

Варијабле мишићне силе добијене на основу мерења и изведене након израчунавања су биле:
- Fмах мишића опружача ногу - просечна вредност максималне мишићне вучне силе (вршне вредности) за мишиће опружаче ногу, изражена у њутнима (N).

- Fмах мишића опружача потколенице - просечна вредност максималне мишићне вучне силе (вршне вредности) за мишиће опружаче потколенице, изражена у њутнима (N).

- Frel. мишића опружача ногу - релативна сила мишића опружача потколенице.

- Frel. мишића опружача потколенице - релативна сила мишића опружача потколенице.

\section{Статистичка анализа}

Сви подаци су подвргнути дескриптивној статистичкој анализи. За анализу силе и перформансе у пливању примењена је вишеструка анализа регресије да би се одредила варијабла која најбоље описује пливање са перајама на 50м и 100м. Вредности су изражене као средње вредности и стандардна девијација. Ниво значајности за све параметре је изржаен у односу на p 0,05. Анализа података је вршена статистичким програмом СПСС 22.

\section{РЕЗУЛТАТИ МЕРЕЊА}

Дескриптивна статистика мерених и израчунатих варијабли је приказана у Табели 1.

Табела 1. Средње вредности и стандардна девијација измерених варијабли

\begin{tabular}{|l|c|}
\hline \multicolumn{1}{|c|}{ Мерени параметри } & $\begin{array}{c}\text { Средња } \\
\text { вредност } \pm \mathbf{C Д}\end{array}$ \\
\hline $\begin{array}{l}\text { Време на 50м у пливању са } \\
\text { перајама (у секундама) }\end{array}$ & $19,8878 \pm 0,92$ \\
\hline $\begin{array}{l}\text { Време на 100м у пливању са } \\
\text { перајама (у секундама) }\end{array}$ & $45,7956 \pm 2,56$ \\
\hline Fмах. мишића опружача ногу (N) & $948,0 \pm 159,17$ \\
\hline $\begin{array}{l}\text { Fмах мишића опружача } \\
\text { потколенице (N) }\end{array}$ & $2872,87 \pm 577,35$ \\
\hline Frel. мишића опружача ногу (N) & $13,31 \pm 2,52$ \\
\hline $\begin{array}{l}\text { Frel. мишића опружача } \\
\text { потколенице (N) }\end{array}$ & $40,15 \pm 7,58$ \\
\hline
\end{tabular}

Вишеструки модел регресије објаснио је 64,1\% зависне варијабле (Adj. R2 =0,641) време пливања са перајама на 50м, (просечан резултат пливања са перајама на 50м $=19,8878 \pm 0,9231$ секунди). Модел регресије за 50м уопштено није био стати- 
стички значајан (Sig..085). Могли бисмо рећи да су ови резултати потенцијално статистички значајни зато што је р мање од 0,100 , што значи да је статистичка вероватноћа 91,5\%. Резултати вишеструке анализе регресије који се тичу пливања са перајима на 50 метара су приказани у Табели 2.

Табела 2. Анализа регресије резултата пливања са перајама на 50м

\begin{tabular}{|c|c|c|c|c|c|c|}
\hline \multicolumn{2}{|c|}{ Модел } & $\begin{array}{c}\text { Збир } \\
\text { квадрата }\end{array}$ & df & $\begin{array}{c}\text { Просек } \\
\text { квадрата }\end{array}$ & F & Sig. \\
\hline \multirow{2}{*}{1} & Регресија & 5,593 & 4 & 1,398 & 4,571 &, $085^{\mathrm{a}}$ \\
\cline { 2 - 7 } & Остатак & 1,224 & 4 &, 306 & & \\
\cline { 2 - 7 } & Укупно & 6,817 & 8 & & & \\
\hline
\end{tabular}

Утврђено је да све појединачне варијабле делимично статистички значајно објашњавају резултате у пливању са перајама на 50м са 0,015, 0,019, 0,016 и 0,020 р нивоа, али као група варијабли не јавља се опште значајно тумачење.

Једначина модела предикције за време за пливање са перајама на 50м је:

50м време пливања са перајама $=25,1023-$ (Legs_Ext_Fmax • 0,1130) + (Ancle_Ext_Fmax • 0,0346) $+($ Legs_Ext_Frel $• 7,7764)-($ Ancle_Ext_ Frel • 2,5149)

Као што је приказано у анализи резултата, релативни резултати (Frel.) на 50м имају већи утицај него апсолутни резултати (Ғмах). Што се тиче резултата пливања са перајима и дисаљком на 100м, није утврђена статистичка значајност. Нити једна варијабла мишићне силе није довољно описала зависну варијаблу - време за пливање са перајама на 100м, све четири варијабле су уклоњене р вредностима $.981, .929, .809$, односно .537 за сваки модел. Даље, није било значајних резултата на делимичном нивоу.

\section{ДИСКУСИЈА}

Резултати ове пилот студије довели су до закључка о потенцијалном статистичком значају обрађене регресионе анализе одабраних параметара у односу на пливање са перајама на 50м са дисаљком на површини воде. Вредности релативне силе мишића опружача потколенице и ноге су могући предиктори за пливање са перајама на 50м. Утврђен је модел предикције, и то: време пливања са перајама на 50м $=25.1023$ - (Legs_Ext_Fmax ・ 0,1130) + (Ancle_Ext_Fmax • $0,0346)+($ Legs_Ext_Frel $・ 7,7764)-($ Ancle_Ext_ Frel • 2,5149)

Нису утврђени слични резултати повезаности мерених и израчунатих параметара за пливање са перајама на 100м. Овакви резултати, вероватно сугеришу да на краћим такмичарским дужинама, као што је пливања перајима на 50м, варијабла силе мишића опружача ногу имају већи значај у поређењу са истим мишићним силама током пливања са перајама на 100м.

Претходна истраживања која су се тицала спортског пливања (Dopsaj et al, 2004) показала су да експлозивност стопала и мишића опружача потколенице, као и мишића леђа, могу бити значајни предиктори перформанси у пливању на 50 и $100 \mathrm{M}$.

У области пливања са монофин перајама не постоји довољно података до којих се дошло мерењем силе мишића ван воде. Већина истраживања која су се тицала пливања са монофин перајама бавила су се кинематичком анализом покрета пераја и самог пливања (Rejman, 2013; Rejman, Klarowicz \& Zaton, 2012).

Потребна су даља истраживања како би се одредила процедура која ће контролисати нивое физичке припремљености пливача на сувом, не само да би се омогућило тачније управљање тренажним процесом било у води, било на сувом, већ и да би се повећала ефективност тренинга и подигао ниво такмичарске припремљености пливача са монофин перајама на кратке стазе.

\section{ЗАКЉУЧАК}

Ограничења ове пилот студије, која се односе на величину узорка, нису могла да доведу до статистички значајног модела регресије за пливање са перајама на 50м, док су сви параметри силе резултирали делимично значајним предикторима.

Недостатак значајних резултата код пливања са перајама на 100 м у овом истраживању, наглашавају потребу даљег истраживања мерења на сувом у вези са пливањем са монофин перајама.

Треба тежити студијама и мерењу које може пружити информације високог квалитета о стварном нивоу тренажне и такмичарске припремљености спортисте. Ови подаци су веома 
важни, како за тренера, тако и за самог спортисту. У односу на исход примењених тренажних метода и статуса физичке припремљености на сувом,

\section{ЛИТЕРАТУРА}

1. Bideau, B., Colobert, B., Fusco, N., Cretual, A., Multon, F., \& Delamarche, P. (2002). How to Compute the Mechanical Parameters of Monofins. Proceedings of Biomechanics and Medicine in Swimming IX. (pp. 505-510). Saint-Etienne, France.

2. Dopsaj, M., Matković, I., \& Zdravković, I. (2000b). The relationship between 50m - freestyle results and characteristics of tethered forces in male sprint swimmers: A new approach to tethered swimming test. Facta Universitatis Series: Physical Education and Sport, 1(7), 15-22.

3. Dopsaj, M., Thanopoulos, V., Race, V., \& Okicic, T. (2004). The relationship between between competitive fitness levels in top sprinters swimmers at 50 and $100 \mathrm{~m}$. freestyle and indicators of explosiveness of different muscle groups: A result prediction model. $4^{\text {th }}$ International Conference on Strength Training. Book of Abstracts (pp 153-154). Serres, Greece.

4. Gautier, J., Baly, L., Zanone,P. G., \&Watier, B. (2004). Effect of practice level and race distance on Kinematics parameters kod plivanja perajima. Sciene \& Sports, 3, 91-95.

5. Nakashima, M., Suzuki, S., \& Nakajima, K. (2010). Development of a simulation model for monofin swimming. Journal of Biomechanical Science and Engineering, 5(4), 408-420.

6. Pendergast, D. R., Tedesco, M., Nawrocki, D. M., \& Fisher, N. M. (1996). Energetics of underwater swimming with SCUBA. Medicine and Science in Sports and Exercise, 28, 573-580. они су у директној вези са експлозивношћу која је основни део тренажне и такмичарске технике пливања са монофин перајама.

7. Popov, F.P. (1982). Preparation of high class sailors (Translation Vourna A.) Athens: EOUDA.

8. Rejman, M. (2013). Analysis of relationships between the level of errors in leg and monofin movement and stroke parameters in monofin swimming. Journal of sports science and medicine, 12, 171-181.

9. Rejman, M., Klarowicz, A., \& Zaton, K. (2012). An evaluation of kinesthetic differentiation ability in monofin swimmers. Human movement, 13(1), 8-15.

10. Sanders R. H., Cappaert J. M., Devlin R. K. (1995) Wave characteristics of butterfly swimming. Journal of Biomechanics 28, 9-16.

11. Tamura H., Nakazawa Y., Sugiyama Y., Nomura T., Torii N. (2002) Motion analysis and shape evaluation swimming monofin. : The Engineering of Sport. Ujihashi S., Haake S.J., editors. Blackwell Science, Vol. 4, 716-724

12. Ungerechts B. E. (1982) A comparison of the movements of the rear parts of dolphins and butterfly swimmers (215-221). Biomechanics and Medicine in Swimming. Hollander A. P., Champaign, Human Kinetics,

13. Videler, J. (1981). Swimming movement, body structure and propulsion. Cod Gadusmorhua, Symposia of the Zoological Society of the London, 48, 1-27.Zammartini, S. (1986). Swimming Training Technique (Translation by Liulias A.) Athens: EOUDA.

14. Zamparo, P., Prendergast, D. R., Termin, B. \& Minetti, A. E. (2002). How fins affect the economy and efficiency of human swimming. Journal of Experimental Biology, 205, 2665-2676 


\title{
MODELO DE PREDICCIÓN DE LA INFLUENCIA DE FUERZA EN LO SECO Y EL RENDIMIENTO EN LA NATACIÓN CON ALETAS - ESTUDIO PILOTO
}

\begin{abstract}
Resumen
El objetivo de la presente investigación es determinar el modelo de predicción que podría prever los resultados de natación con aletas a $50 \mathrm{~m}$ y a $100 \mathrm{~m}$. La muestra de esta investigación han sido los 9 nadadores con aletas a nivel de competencia. Todos los participantes nadaron con la intensidad máxima con aletas monofin con tubo respetador a 50 y a 100 metros en la superficie del agua. En dos siguientes fases la fuerza de los músculos extensores de piernas y de los musculáis extensores de pierna inferior se ha medido en el gimnasio por dinamómetro. Los resultados de esta investigación han llevado hasta la conclusión sobre la posible importancia estadística del análisis de regresión de la natación con aletas a $50 \mathrm{~m}$ con tubo respirador en la superficie del agua. Los valores de la fuerza relativa de los músculos extensores de la pierna inferior y de la pierna son mejores predictores para la natación a $50 \mathrm{~m}$ con aletas. Los resultados parecidos no se han obtenido en la natación con aletas a $100 \mathrm{~m}$. Estos descubrimientos probablemente sugieren que a distancias más cortas en la natación con aletas a $50 \mathrm{~m}$ las variables de fuerza de los músculos extensores juegan un mayor papel en comparación con la natación a una mayor distancia, natación con aletas a $100 \mathrm{~m}$. La medición de la fuerza de las piernas en la natación con aletas tiene una importancia especial teniendo en cuenta que las piernas en general son responsables para la propulsión en la natación con aletas y hace falta seguir investigando con otros protocolos de fuerza, distintos ejercicios y en una muestra mayor.
\end{abstract}

Palabras claves: MEDICIÓN EN LA NATACIÓN/ DINAMOMETRÍA / ALETAS MONOFIN / MODELO DE LA PREDICCIÓN

Примљен: 11. 06. 2017.

Прихваћен: 04. 12. 2017. 